\title{
German and Austrian Foreign Direct Investment in Brazilian Regions: Which Are the Location Choice Factors?
}

\author{
Romana Korez-Vide ${ }^{1}$, Patrick Voller ${ }^{2} \&$ Vito Bobek $^{2}$ \\ ${ }^{1}$ Faculty of Economics and Business, University of Maribor, Slovenia \\ ${ }^{2}$ FH Joanneum Graz, University of Applied Sciences, Austria \\ Correspondence: Romana Korez-Vide, PhD, Assistant Professor, Faculty of Economics and Business, University of \\ Maribor, Slovenia. E-mail: romana.korez-vide@uni-mb.si \\ Received: September 19, 2014 \\ Accepted: October 6, 2014 \\ Online Published: October 16, 2014 \\ doi:10.5430/jms.v5n4p68 \\ URL: http://dx.doi.org/10.5430/jms.v5n4p68
}

\begin{abstract}
Due to the liberalization and transformation of emerging markets economies, the attractiveness of these countries for foreign direct investors has been rising in the last decades. This paper explores foreign direct investment location choice factors of German and Austrian companies in Brazilian regions. We perform the quantitative analysis, based on the Multinomial Nested Logit Model and supplement its findings by the qualitative analysis, based on the semi-structured experts' interview. The analyses shown that investor-nation specific agglomeration, industry specialization, workforce qualification and physical infrastructure were important FDI location choice factors for German and Austrian companies in Brazil. Suggestions for future research of the FDI location choice factors are discussed.
\end{abstract}

Keywords: foreign direct investment, location choice factors, MNEs, emerging markets, agglomerations, Multinomial Nested Logit Model, Germany, Austria, Brazil

\section{Introduction}

Market liberalization in many emerging markets over the past two decades has led to lower entry barriers and easing of restrictions on foreign direct investment (FDI). As a result, high-growth emerging markets have been attracting multinational enterprises (MNEs) in increasing numbers. The pace of foreign entry in emerging economies has dramatically accelerated in recent years, with these countries now accounting nearly half of G-20 foreign direct investment (FDI) inflows (OECD, 2013). In Brazil, the ratio of FDI inflows to the country's GDP increased from a $1.9 \%$ average in the 1990 's to $2.5 \%$ average from 2001 to 2010 (UNCTAD, 1992; 2012). With a $2.7 \%$ average ratio of FDI inflows in GDP from 2011 to 2012, Brazil was on the second place among the eight non-OECD G-20 countries. In 2012 Brazil was regarded as one of the three most attractive FDI locations worldwide (A.T. Kearney, 2013).

Despite its increasing attractiveness as FDI location, Brazil has received little attention in terms of studies on national FDI determinants (e.g. Nelson, 2002; Maniam, 2007; DeAngelo et al., 2010; Kang and Huang, 2012) and on regional FDI determinants in particular (e.g. Sridhar and Wan, 2007; Bortoluzzo et al., 2012). In the current state of the academic literature there is also a lack of studies of German and Austrian companies' investment behaviour in emerging markets.

The goal of this paper is to find out, which factors are attracting German and Austrian MNEs to invest in certain Brazilian regions. Both countries have a similar industrial structure, with a large share of industries which require high precision with specialized technology. As those industries are operating in niche markets, they can only grow through global expansion. However, one of the current problems of Austrian and German investment abroad is its high concentration within the European Union (EU). This can pose a great risk in the period of regional slowdown. Therefore, the diversification of German and Austrian activities in different world regions has to become a priority. Such a direction is particularly important for countries with limited home market, like Austria.

A rough prior insight into the distribution of German and Austrian FDI in Brazil has shown that they are mostly concentrated in the Brazil's capital and in some other big cities. Therefore, in the theoretical part of our paper the importance of agglomerations as FDI location choice factors is explored. Additionally, according to the research 
question of our paper, the scholars' findings on FDI determinants at the regional level are examined. Due to the lack of studies on FDI location choice factors, which check their quantitative analysis results with qualitative data, and since the purely quantitative research approach to this topic was criticized in the past (e.g. Martin, 1999; Neary, 2000), the empirical part of our paper is structured into quantitative and qualitative research. The goal of the quantitative empirical study is to statistically test the stated hypotheses, whilst the goal of the qualitative research is to gain insight into the importance of selected FDI location choice factors and to make the quantitative empirical study more robust.

\section{Theoretical Background and Hypotheses}

\subsection{The Concept of Agglomerations in Economics}

In the last two decades several scholars have studied the concept of agglomerations in economics (e.g. Arthur, 1990; Glaeser, Kallal and Scheinkman, 1992; Henderson, Kuncoro and Turner, 1995; Audretsch and Feldman, 1996; Ellison and Glaeser, 1997; Shaver and Flyer, 2000; Henderson, 1997; Hilber and Voicu, 2007), which gives an explanation for different degrees of economic density in countries.

Research on MNEs entry into foreign markets suggests that foreign firms suffer from a liability of foreignness due to a "foreign firm's unfamiliarity with the local culture and other aspects of the local market" (Zaheer and Mosakowski, 1997, p. 440; Lamin and Livanis, 2013, p. 582). Knowledge about the host environment is important in all countries, but may be particularly so in emerging markets, as laws and regulations can be subject to "interpretation" and haphazard application with limited recourse (Meyer, Wright and Pruthi, 2009). For foreign firms, one way to mitigate their higher information and search costs is to locate near other firms. Co-location or agglomeration creates opportunities for entrants to develop relationships with other firms "willing to share relevant local knowledge" (Tan and Meyer, 2011, p. 505). Thus, foreign investors use the presence of other firms to guide their location decisions as a means of compensating for their unfamiliarity with the foreign market. The liability of foreignness literature emphasizes that, although domestic firms may be the best sources of local knowledge, foreign entrants may find it more difficult to establish relationships with these firms than with other foreign firms (Lamin and Livanis, 2013, p. 586). Managers of foreign firms are likely to be familiar with other foreign entrants, as these firms encounter each other in multiple markets (Cantwell and Mudambi, 2011). Foreign entrants may look to other foreign firms to provide guidance on how to deal with simultaneous pressures from the parent firm as well as the host country (Kostova and Zaheer, 1999; Meyer et al., 2011). Empirical evidence strongly supports the idea that an existing foreign base in a location attracts additional foreign entry (Chang and Park, 2005; Tan and Meyer, 2011; Belderbos et al., 2011; Mukim and Nunnenkamp, 2012; Lee et al., 2012).

\subsection{FDI Location Choice Factors at the Regional Level}

Several scholars have studied FDI decision choice factors at the regional level in developed countries (e.g. Coughlin and Terza, 1987; Kozlowski and Weekly, 1990; Ulgado and Yu, 1991; Ulgado and Lee, 2004; Büttner and Ruf, 2004; Head, Ries and Swenson, 1995; Huallachain and Breandan, 1997; Zhou, Delios and Yang, 2002; Blonigen, Ellis and Fausten, 2003; Chung and Alcácer, 2002; Cobos, Görg and Strobl, 2002; Carod, 2005; Crozet, Mayer and Mucchielli, 2004; Kandogan, 2012; Kornecki and Ekanayake, 2012; Dimitropoulou, Burke and McCann, 2013). According to the research question of our paper, in this section we focus on the literature on FDI location choice factors at the regional level in developing and transition countries.

In their study about the FDI location decision of Japanese investments in China, Belderbos and Carree (2002) found that there is a difference in the locational investment criteria between Japanese small and medium-sized companies (SMEs) and MNEs. Unlike Japanese MNEs, Japanese SMEs tend to cluster next to the other Japanese companies and geographically closer to their headquarters in Japan. Therefore, agglomeration of Japanese companies in China was a strong and significant FDI determinant for Japanese SMEs (ibid., p. 16). In the Turkish case, Deichmann, Karidis and Sayek (2003) gave evidence that foreign direct investors prefer the proximity of agglomerations in their location choice decisions. Furthermore, it was found that investors locate in urban areas with coastal access and a highly educated workforce (ibid., 2003, p. 1778). In their study about FDI in transition economies Kinoshita and Campos (2003) found that the most important determinants of the location of FDI are agglomerations and the quality of institutions. Especially a cumbersome bureaucracy and a weak rule of law are deterrents to foreign investors (ibid., p. 21). A study about regional determinants of FDI in China by Na and Lightfoot (2006) found that GDP per capita and the quality of labor were statistically significant attraction factors for FDI (ibid., p. 275). For Romania, Hilber and Voicu (2007) found evidence for the strong significant influence of foreign and domestic industry-specific agglomerations and service agglomerations. The high importance of service agglomerations led to the assumption that foreign investors locate near metropolitan areas (ibid., p. 21). Binh (2010) found that foreign investors in 
Vietnam are influenced by the location choice of other foreign investors before. Especially, when these other investors operated in the same industry or came from the same country. The location decision of other Vietnamese companies had no effect on the choice made by foreign investors (ibid., p. 20). A study about the regional FDI determinants of U.S. MNEs in China by Du, Lu and Tao (2008) revealed that U.S. MNEs invest in regions with other US firms of the same industry, with clusters of Chinese firms in the same industry and with the access to the market and the suppliers (ibid., p. 423). By looking at Russia, Buccllato and Santangelo (2009, p. 15) provided evidence that FDI were mainly driven by vertical specialization and agglomeration. The study of Chidlow, Salciuviene and Young (2009) showed that foreign investors in Poland were attracted by agglomeration, knowledge and market factors in the strongest urban and business service agglomeration and the richest region of the country. However, investors interested in low input costs, availability of labour and natural resources were attracted by other regions (ibid., $p$. 129). Ledyaeva, Karhunen and Kosonen (2010) found that for Chinese, Japanese and US investors market potential of Russian regions was an important FDI location choice factor. Agglomerations of companies from the same investor country and in the same industry had a further strong significant impact on the investment decision of the involved investor nations (ibid., p. 16). In their study about regional determinants of FDI in China, Boermans, Roelfsema and Zhang (2011) found that labor costs and infrastructure are the main determinants for regional FDI location decisions. Furthermore, regional FDI in China was strongly drawn by agglomerative forces (ibid., p. 21). In their study about regional FDI determinants in India, Mukim and Nunnenkamp (2012) found that foreign direct investors strongly preferred locations that other foreign direct investors had chosen before them. Furthermore, foreign investors valued the availability of qualified labor force, a good investment climate and good infrastructure (ibid., p. 908). Bortoluzzo et al. (2012) found that general FDI determinants in Brazil in 2010 on regional level were the size of the regional market, the quality of the workforce and the quality of infrastructure. Inward FDI into various Brazilian federal states was negatively affected by the level of taxes and labor costs (ibid., p .16).

\subsection{The FDI Location Choice Factors of Interest}

In order to determine the FDI location choice factors of interest at the regional level more precisely, the frequency of particular FDI determinants was counted across the 16 studies on location determinants in developed and 11 studies on location determinants in developing and transition countries. The FDI location choice factors of interest constitute the pillars of our qualitative and quantitative empirical research. The results of the cross-study comparison revealed that the findings of academic studies in developed and developing countries differ. However, there are relatively common and strong FDI location choice factors supported by the research in both groups of countries. These factors are market potential, general agglomeration and network effects. As workforce education seems to be a highly important factor in developing countries as well, it is included as the factor urban agglomeration. The FDI location choice factors of interest are reflected in the following hypotheses:

H0: Market size is not the dominant FDI location choice factor of German and Austrian FDI at the regional level in Brazil.

H1: Market size is the dominant FDI location choice factor of German and Austrian FDI at the regional level in Brazil.

H2: General agglomeration has a significant positive influence on FDI location choice of German and Austrian FDI at the regional level in Brazil.

H3: Urban agglomeration has a significant positive influence on FDI location choice of German and Austrian FDI at the regional level in Brazil.

H4: Network effects have a significant positive influence on FDI location choice of German and Austrian FDI at the regional level in Brazil.

H5: The degree of workforce education has a significant positive influence on FDI location choice of German and Austrian FDI at the regional level in Brazil.

H6: The industry of the investor has a significant influence on FDI location choice of German and Austrian FDI at the regional level in Brazil.

\section{Quantitative Research}

\subsection{Data Sources and Sampling}

The data sources used for the quantitative research include disaggregated firm-level data for German and Austrian companies, as well as the FDI location choice specific information of Brazilian federal states. The first source of information was a dataset of German and Austrian merger transactions in Brazil, which was retrieved from the Thomson Reuters M\&A Database. The second source of information was the company membership lists of the 
German-Brazilian Chamber of Commerce and the Austrian Trade Commission in Brazil. All companies at these lists, which had published their year of investment and corresponding investment location through public channels, were added to the sample.

Following the described method, a sample of 222 complete datasets could be gathered. This sample contained 36 Austrian companies' investment and 186 German companies' investment in Brazil. Therefore, taking into account the approximately 570 German companies (Deutsche Bundesbank, 2013) and the approximately 200 Austrian companies active in Brazil (Austrian Trade Commission Brazil, 2013), the sample represented 33\% of all companies in the German and $18 \%$ of all companies in the Austrian case.

This sample had also been used to conduct some data analysis prior to the statistical analysis concerning the distribution of German and Austrian FDI in Brazil. From the 222 investments in the total sample, 138 were directed towards the state of Sao Paulo. Although Brazil has 26 federal states and one federal district, which could serve as investment location alternatives, only 6 Brazilian federal states have absorbed approximatley $98 \%$ of all German investment. These states were Sao Paulo, Rio de Janeiro, Minas Gerais, Parana, Rio Grande do Sul and Santa Catarina. Within the aforementioned target investment states, São Paulo has received $60 \%$ of German investment (German-Brazilian Chamber of Commerce and Industry, 2013). However, the peripheral regions along the highways, which lead to the interior of the federal state, have also shown higher concentration in FDI. The farer away from the city itself, the sparser investment became. The federal state of Parana received investment of 28 companies or approximately $12 \%$ of the total incoming Austrian and German FDI in the sample (German-Brazilian Chamber of Commerce, 2013; Austrian Trade Commission Brazil, 2013). The investment location was highly concentrated in the city of Curitiba and Sao José dos Pinhais. Rio de Janeiro absorbed 22 companies' investment of our sample, which equals $10 \%$. Similar to the case of Sao Paulo, the city of Rio de Janeiro, including some of its more peripheral smaller cities, hosted most of German and Austrian FDI in this state. The state of Rio Grande do Sul absorbed 14 companies' investment or approximately $6 \%$ of Austrian and German investment. Apart from the city itself, smaller peripheral cities like Sao Leopoldo and Canoas and other cities more in the interior of the state, like Caixas do Sul and Passo, have been attractive investment locations, as well. Minas Gerais received 11 investments or 5\% of Austrian and German FDI in our sample. Nearly all investment was concentrated in the capital city of Belo Horizonte and some bordering cities like Sete Lagoas or Nova Lima. The state of Santa Catarina, absorbed 9 companies investment, which equals a 4\% share of our sample. The investment in this city was not concentrated in a single city, but spread out in various smaller cities and tend to be located near the sea.

\subsection{Quantitative Research Method Selection}

Based on the frequency distribution among the research methods used - the sample consisted of the same above mentioned studies from which the FDI location factors of interest were extracted - it was decided to put the main focus of the empirical research on a quantitative research method, which would be a Conditional Logit Model (CLM), a Negative Binomial/Poisson Model or a Multinomial Nested Logit Model (MNLM), derived from a Discrete Choice Model (DCM) developed by McFadden (1973). A DCM has been widely used to examine FDI location choice factors (e.g. Shaver and Flyer, 2000; Alcácer and Chung, 2007; Tan and Meyer, 2011). In spite of their identical coefficient estimations, three variations of a DCM behave quite differently, which has implications for the attractiveness of the FDI locations (Schmidheiny and Brulhart, 2009, p. 214). The MNLM adopts certain characteristics in its behaviour from the CLM - the competing behaviour between investment regions within a certain subset - and others from the Poisson Model - a change in the region's investment attractiveness will affect the total number of firms investing (ibid., p. 217). Taking into account the different investment probability estimations of the different models, it was decided that the MNLM represents the middle way and the appropriate choice of the quantitative research method.

\subsection{Research Design}

By using the MNLM, it was necessary to design the nests, or investment level tree structure (see Schmidheiny and Brulhart, 2009). Taking into consideration the distribution of our sample data, we assume that some investment locations in Brazil are closer substitutes than others. Therefore, the following investment level tree structure is proposed (Figure 1): 


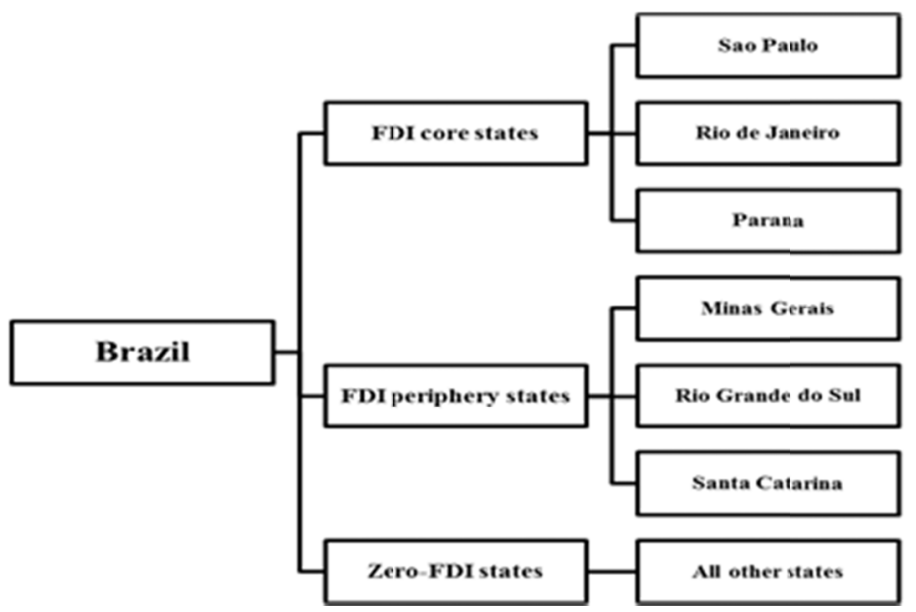

Figure 1. Investment level tree structure

Source: authors.

The Brazilian federal states of Sao Paulo, Rio de Janeiro and Parana absorbed most of the incoming FDI of German and Austrian companies, which was directed towards Brazil. Therefore, these three states, which are also situated in a relatively small geographical distance from each other, represent the core FDI states in our sample. It is assumed that Sao Paulo, Rio de Janeiro and Parana are closer substitutes for FDI and that there is more rivalry for investment between these three federal states compared to other Brazilian federal states. The Brazilian federal states of Minas Gerais, Rio Grande do Sul and Santa Catarina also have received Austrian and German FDI, but in a much lower quantity than it is the case with the FDI core states. Therefore, it is assumed that any investor who does not consider locating in one of the FDI core states, will as a next step decide whether to locate in one of the FDI peripheral states. This implies that the Minas Gerais, Rio Grande do Sul and Santa Catarina are closer substitutes for FDI compared to each other than to the other states and compete for FDI projects more closely. Out of 27 Brazilian federal states, our sample does not contain any Austrian and German FDI projects in 21 states. This fact is a sign of the unequal distribution of FDI among Brazilian states. Hence, these 21 zero-FDI states do not compete equally for FDI projects as the states in the other sub-groups and thus, constitute a subgroup in their own right.

The presented total sample was the basis for the final sample. In the final sample, the location specific and investor specific variables got matched in order to fulfil the requirements of the MNLM. Due to the scarcity of continuous time series data with regard to the Brazilian federal states, the final time period under observation was defined as the period from 2001 to 2011. This resulted into a sample of 122 companies' investment and a total of 735 choice observations.

\subsection{Data Variables}

In order to analyse the FDI location decisions through a statistical discrete choice model, investment location alternative and optionally investor specific variables needed to be defined. These variables served as proxies for the FDI location choice factors of interest (Table 1).

Table 1. Data variables - quantitative research method

\begin{tabular}{|c|c|c|c|}
\hline $\begin{array}{l}\text { Explaining } \\
\text { variable }\end{array}$ & Proxy & $\begin{array}{l}\text { Exp. } \\
\text { sign }\end{array}$ & Academic articles \\
\hline \multirow{2}{*}{$\begin{array}{l}\text { Market } \\
\text { Potential }\end{array}$} & $\begin{array}{lccc}\begin{array}{l}\text { Population; } \\
\text { population } \\
\text { population }\end{array} & \begin{array}{c}\text { Share } \\
\text { related }\end{array} & \begin{array}{l}\text { of } \\
\text { to }\end{array} & \begin{array}{l}\text { state } \\
\text { total }\end{array} \\
& & & \end{array}$ & + & $\begin{array}{l}\text { Chidlow et al. (2009) } \\
\text { Binh (2010) } \\
\text { Bortoluzzo et al. (2012) }\end{array}$ \\
\hline & $\begin{array}{l}\text { Market demand; Annual } \\
\text { electronic consumption per capita } \\
\text { MwH }\end{array}$ & + & $\begin{array}{l}\text { Basile (2002) } \\
\text { Sethi, Judge and Sun (2011) }\end{array}$ \\
\hline Agglomeration & $\begin{array}{l}\text { Industry density; Number of } \\
\text { manufacturing jobs per } \mathrm{km}^{2}\end{array}$ & + & $\begin{array}{l}\text { Guimaraes, Figueiredo and } \\
\text { Woodward (2000) } \\
\text { Belderbos and Carree (2002) }\end{array}$ \\
\hline
\end{tabular}




\begin{tabular}{|c|c|c|c|}
\hline & & & Alcácer and Chung (2007) \\
\hline & $\begin{array}{l}\text { Urban density; Share of } \\
\text { metropolitan population related to } \\
\text { federal state population }\end{array}$ & + & Glickman and Woodward (1988) \\
\hline & $\begin{array}{l}\text { Network effect - } \\
\text { Accumulated FDI-stock of } \\
\text { Austrian and German companies } \\
\text { in a federal state }\end{array}$ & + & $\begin{array}{l}\text { Guimaraes, Figueiredo and } \\
\text { Woodward (2000) } \\
\text { Belderbos and Carree (2002) } \\
\text { Disdier and Mayer (2004) }\end{array}$ \\
\hline Education & $\begin{array}{l}\text { Knowledge worker availability; } \\
\text { Nr. of federal state students with } \\
\text { higher education }\end{array}$ & + & $\begin{array}{l}\text { Békés (2005) } \\
\text { Chidlow et al.(2009) } \\
\text { Law (2010) }\end{array}$ \\
\hline Industry & $\begin{array}{l}\text { Industry groups defined by the } \\
\text { author }\end{array}$ & $\begin{array}{c}\text { No } \\
\text { expectation }\end{array}$ & \\
\hline
\end{tabular}

Source: authors.

Notes: statistical sources for proxies are The Brazilian Institute of Geography and Statistics (IBGE), Brazilian Ministry of Mines and Energy, Thompson Reuters M\&A Database, The German-Brazilian Chamber of Commerce and The Austrian Trade Commission in Brazil.

The variable "industry" was not used in this way in the revised literature and represents move towards a discrete choice model, which accounts for investor specific information. However, the influence of industry in location choices was discussed in the literature review, where it was discussed as industry-specific agglomerations. For the measurement of the industry, the authors organized the final sample of 14 main industries (Automotive, Machine Engineering, Plastics, Transport, Metal, Glass, Natural Resources, Electrical Engineering, Pharmacy, Chemistry, Materials, Services and IT, Agriculture and Others).

\subsection{Data Analysis}

Due to its powerfulness in terms of functionality, the software STATA was chosen to run the statistical analysis in this paper. The STATA function ASCLOGIT (Alternative Specific Logit) allows the use of a base or default alternative. Taking into account the unequal distribution of FDI in Brazil and the dominant position of the state of Sao Paulo, Sao Paulo is the base alternative for which no results are reported. This mechanism simplifies the prior defined nest structure. The investment observations were due to the specificity of the topic probably not big enough to derive meaningful results from the model, therefore we omitted the zero-investment states in the model, which is according to the academic literature (Belderbos and Carree, 2002, p. 14) a viable and possible solution.

\subsection{Results}

The general characteristics of the statistical analysis are demonstrated in the Figure 2. The number of cases represents the observed amount of German and Austrian company specific investments in Brazil. Each investment chose between 6 alternative Brazilian federal states, which results into a total of 726 observations. Furthermore, the model also demonstrates a Wald test. The test shows that there is a statistical significant improvement through the choice of the independent variables at a $97.52 \%$ statistical confidence level and a $2.48 \%$ statistical significance level.
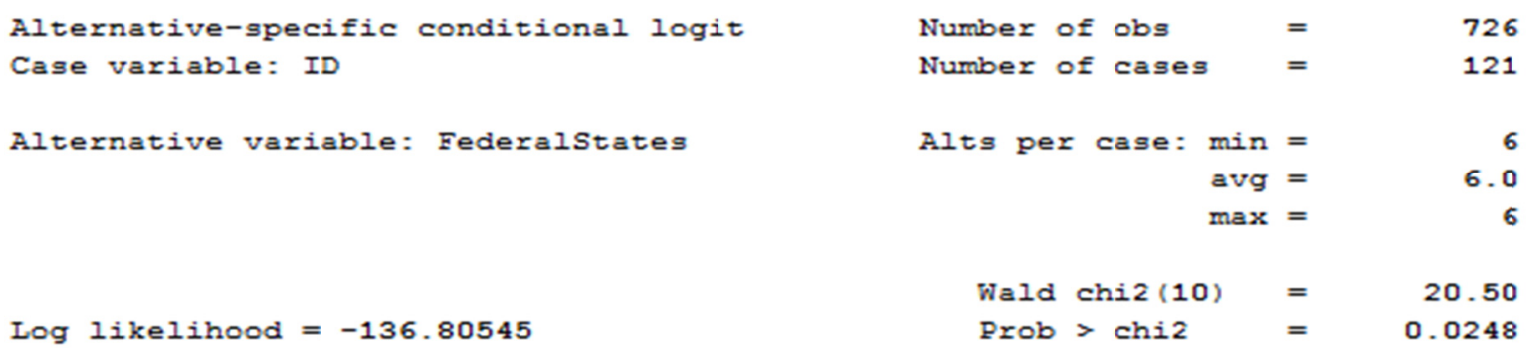

Figure 2. Statistical tests of logistic regression

Source: authors. 
The results of the logistic regression, as illustrated in the Figure 3, encompass all Brazilian federal states, which received observed company specific German and Austrian FDI. As Sao Paulo received by far the biggest share of these FDI, it serves as a base alternative. Therefore, the state of Sao Paulo would be the natural primary choice as investment location for German and Austrian companies. However, as other Brazilian states were also chosen as business location, the regression shows which FDI location choice factors of interest had a significant influence for choosing a state different from Sao Paulo.

\begin{tabular}{|c|c|c|c|c|c|c|}
\hline Choice & Coef. & Std. Exx. & $z$ & $P>|z|$ & [95\& Conf. & Intervall \\
\hline \multicolumn{7}{|l|}{ Federalstates } \\
\hline UrbAggl & .9989188 & 9.216733 & 0.11 & 0.914 & -17.06555 & 19.06338 \\
\hline Ind $\equiv m p 10 y \mathrm{Km}$ & -3.476058 & 3.155896 & -1.10 & 0.271 & -9.6615 & 2.709384 \\
\hline Electrcon & -4.975081 & 3.311508 & -1.50 & 0.133 & -11.46552 & 1.515355 \\
\hline EduSupPop & -3.795228 & 2.215906 & -1.71 & 0.087 & -8.138323 & .5478675 \\
\hline NetEff & -4.091384 & 1.964983 & -2.08 & 0.037 & -7.942679 & -.2400884 \\
\hline \multicolumn{7}{|l|}{ MG } \\
\hline IndustryCode & -.0200656 & .1008521 & -0.20 & 0.842 & -.217732 & .1776008 \\
\hline _cons & -26.83012 & 14.5509 & -1.84 & 0.065 & -55.34937 & 1.689128 \\
\hline \multicolumn{7}{|l|}{ PR } \\
\hline IndustryCode & .1009781 & .0722575 & 1.40 & 0.162 & -.0406439 & .2426001 \\
\hline _cons & -20.20691 & 17.86056 & -1.13 & 0.258 & -55.21297 & 14.79915 \\
\hline \multicolumn{7}{|l|}{ RJ } \\
\hline IndustryCode & .2212599 & .0868969 & 2.55 & 0.011 & .0509452 & .3915746 \\
\hline _cons & -17.26152 & 7.862124 & -2.20 & 0.028 & -32.671 & -1.852037 \\
\hline \multicolumn{7}{|l|}{ RS } \\
\hline IndustxyCode & .1947346 & .1041485 & 1.87 & 0.062 & -.0093926 & .3988618 \\
\hline -cons & -25.56362 & 16.37028 & -1.56 & 0.118 & -57.64879 & 6.521544 \\
\hline \multicolumn{7}{|l|}{ sc } \\
\hline Industrycode & .076177 & .1094672 & 0.70 & 0.486 & -.1383747 & .2907286 \\
\hline _cons & -10.09175 & 154.9155 & -0.07 & 0.948 & -313.7205 & 293.537 \\
\hline
\end{tabular}

Figure 3. Results of logistic regression

Source: authors.

\subsection{Findings and Their Interpretation}

Based on the quantitative research, the findings on the accuracy of the stated hypotheses are the following:

H0: Market size is not the dominant FDI location choice factor of German and Austrian FDI at the regional level in Brazil.

The null hypothesis (H0) was corroborated. Therefore, market size measured by annual electrical consumption per capita is not the dominant FDI location choice factor at the regional level in Brazil.

H1: Market size is the dominant FDI location choice factor of German and Austrian FDI at the regional level in Brazil.

As the null hypothesis was corroborated, hypothesis 1 (H1) was refuted. Market size, measured by annual electrical consumption per capita is not a dominant or even significant FDI location choice factor at the regional level in Brazil.

H2: General agglomeration has a significant positive influence on FDI location choice of German and Austrian FDI at the regional level in Brazil.

Hypothesis 2 (H2) was refuted. General agglomeration estimated by annual industrial employment per federal state $\mathrm{km}^{2}$ was not a significant FDI location choice factor at the regional level in Brazil.

H3: Urban agglomeration has a significant positive influence on FDI location choice of German and Austrian FDI at the regional level in Brazil. 
Hypothesis 3 (H3) was refuted. Urban agglomeration estimated by the number of people living in metropolitan areas was not a significant FDI location choice factor at the regional level in Brazil.

H4: The network effects have a significant positive influence on FDI location choice of German and Austrian FDI at the regional level in Brazil.

Hypothesis 4 (H4) was corroborated. The network effects, estimated by the total observed number of German and Austrian companies active at a given time in a Brazilian federal state, had a significant influence on regional FDI location choice in Brazil above the $95 \%$ confidence level. The Network Effect is measured by the quantity of German and Austrian companies, which settled in a federal state before the new particular FDI location was made. On the one hand, this proxy represents some kind of a nation-specific agglomeration; on the other hand, it could also represent a strategic interaction between suppliers, customers and competitors.

H5: The degree of workforce education has a significant positive influence on FDI location choice of German and Austrian FDI at the regional level in Brazil.

Hypothesis 5 (H5) was corroborated. Workforce education, estimated by the total observed number of students being educated in tertiary education, had a weak significant influence on FDI location choice at the regional level in Brazil above the $90 \%$ confidence level.

H6: The industry of the investor has a significant influence on FDI location choice of German and Austrian FDI at the regional level in Brazil.

Hypothesis 6 (H6) was corroborated. Industry, estimated by a self-developed industry code, had a significant influence on FDI location choice at the regional level in Brazil above the $95 \%$ confidence level. This finding was confirmed for two Brazilian regions - Rio de Janeiro and Rio Grande do Sul - since half of all observed German and Austrian FDI in these two regions came from the IT and services industries. This finding shows that industry specialization might be an important driver for German and Austrian FDI in some particular Brazilian federal states. However, as the analysis showed, the significance of industry as influencing factor for FDI location decisions just holds for two particular federal states and not for the whole sample of companies.

\section{Qualitative Research}

\subsection{The Rationale behind Using Qualitative Research}

The first reason behind that decision is that the quantitative research method used in this paper is not without limitations. The CLM and its derived Multinomial Nested Logit Model have a strong focus on the properties of the business location as explanatory variables for FDI location choice. Hence, gathering primary data from the actual decision makers and taking into account their subjective motives for selecting a business location puts a balance on the overall results obtained and helps to interpret the outcome of the quantitative statistical analysis more cautiously. In other words, the qualitative research part promotes a more holistic view on the topic of this paper. The second reason behind that decision is the fact, that he sole use of quantitative methods has been criticized by economic geographers as these models may miss some important, but often immeasurable interaction of social, institutional, economic and geographic variables (e.g. Martin, 1999, p. 70; Neary, 2000). In order to meet the goals of the study, we follow Mayring's (2001) "Vertiefungsmodell", which describes a particular combination of qualitative and quantitative research. The advantage of this method is that it serves as an auxiliary tool to better understand the results obtained by the quantitative analysis and provide insights for its interpretation.

\subsection{Selection of the Qualitative Research Method}

All qualitative research methods found in the revised academic papers about FDI location choice used interviews or surveys. Therefore, this paper also applied interviews as its core qualitative research method. The interviews were semi-structured by following a pre-designed interview guide, but also providing space for new ideas from the interviewees. The qualitative research in this paper had an auxiliary character and did not intend to corroborate or falsify any of the hypotheses stated. Hence, the sample size does not need to meet an extent, which would allow for testing these hypotheses. Therefore, the sample size for the qualitative research was defined as the amount of interviews necessary to gain novel insights, which had not been expressed in prior interviews. Despite its industrial diversity all interviewed companies operated in the business-to-business (B2B) sector and were oriented towards sales of mainly imported high-tech products. We interviewed companies in the field of engineering services, sales of test equipment, sales and production of high-tech products for the food industry and sales of metal products. 


\subsection{Interview Guide}

In order to conduct semi-structured expert interviews with company representatives in Brazil, an interview guide was designed. This interview guide contained specific topics of interest, which in some cases were equivalent to the FDI location choice factors of interest, defined in the quantitative research, and in other cases defined alternative factors, which were also present in similar revised FDI location choice studies, but were difficult to quantify due to the nature of the topic or the unavailability of data for Brazilian federal states in the time period under observation. The topics that were part of the interview guide are shown in the Table 2.

Table 2. FDI location factors of interest in the qualitative research

\begin{tabular}{ll}
\hline Qualitative FDI factor of interest & Description \\
\hline $\begin{array}{l}\text { Influence of Brazilian, German, } \\
\text { Austrian or international clients, } \\
\text { competitors and suppliers }\end{array}$ & $\begin{array}{l}\text { This topic is also part of the quantitative research, where it is labelled } \\
\text { between company agents had an influence on location choice. }\end{array}$ \\
\hline $\begin{array}{l}\text { General motives for entering the } \\
\text { market }\end{array}$ & $\begin{array}{l}\text { This topic investigates what the general motive for entering the } \\
\text { Brazilian market was and shall investigate, whether the company was } \\
\text { driven by the market, by resources, cheap labor or any other reason. }\end{array}$ \\
\hline $\begin{array}{l}\text { Influence of employee qualification } \\
\text { and productivity }\end{array}$ & $\begin{array}{l}\text { This topic is also part of the quantitative research, where it is labelled } \\
\text { as "Knowledge worker availability". It investigates whether } \\
\text { companies perceive differences in labor qualification and } \\
\text { productivity among Brazilian regions or even sub-regions and } \\
\text { whether this is a location choice criterion. }\end{array}$ \\
\hline $\begin{array}{l}\text { Influence of the road and railway } \\
\text { system }\end{array}$ & $\begin{array}{l}\text { This topic investigates, whether the degree of development of the } \\
\text { road and railway system has an influence on the FDI location choice } \\
\text { decisions. }\end{array}$ \\
\hline $\begin{array}{l}\text { Criteria for future investments in } \\
\text { current "zero-FDI states" }\end{array}$ & $\begin{array}{l}\text { This topic investigates the general preconditions to start a FDI } \\
\text { project in the Northeast of Brazil. The Northeast region is according } \\
\text { to our sample a "zero-FDI state". }\end{array}$ \\
\hline $\begin{array}{l}\text { Influence of the possibility to use } \\
\text { location as export platform }\end{array}$ & $\begin{array}{l}\text { This topic investigates, whether the possibility to use Brazil as an } \\
\text { export platform for other MERCOSUR countries or even Latin } \\
\text { America as a whole has an influence on the regional FDI location } \\
\text { choice within Brazil. }\end{array}$ \\
\hline $\begin{array}{l}\text { This topic investigates, whether individual tax incentives offered by } \\
\text { Brazilian regional governments have an influence on the FDI } \\
\text { location choice within Brazil. }\end{array}$ \\
\hline
\end{tabular}

Source: authors.

\subsection{Interview Partners}

The interview partners should have a direct experience with FDI location choice decision making. Therefore, it was decided to choose company representatives of Austrian companies, which are active in Brazil and work in the international sales and business development departments of these companies. Furthermore, the interviewees came from companies, which operate in four different industries - plastics, machine engineering, food and metal.

\subsection{Findings and Their Interpretation}

The FDI location factor "company network", which defines that one company locates in an area because other companies are also located in this area and thus have invested before, was found to be the main reason for investment location by all four interviewed companies. One interviewee mentioned that he located because of a partner company. The other three interviewed companies stated that they prefer and are expected to locate close to their customers. As their competitors seem to think in the same way, companies which compete with each other also end up locating close to each other. As we asked companies from different industries, the findings of this category are not necessarily industry dependent. However, as the sample mostly represented companies, which exclusively sell imported goods in Brazil and are in the B2B industry, the results obtained could hint that these types of companies put a very high importance on locating near its customers. The FDI location factor "proximity to metropolitan areas" was found to be highly important factor, as well. This factor describes whether a company prefers to locate near a big city or not. 
All interviewed companies were located close to the biggest city in Brazil, Sao Paulo. Two companies stated that they located close to a big city because of the higher availability of a good qualified labor force with a technical background. One company mentioned that the proximity to an international airport was a very important factor for locating close to Sao Paulo, whereas another interviewee mentioned the close distance to the international port of Santos as a very important investment criteria. One company said that a city also provides a net of important personal connections, which facilitate doing business. The FDI location factor "workforce qualification and productivity" describes that companies prefer to locate close to a pool of highly educated and productive employees. Two interviewed companies stated that they need sales people with technical knowledge and preferably a decent knowledge of English language. All interviewed companies claimed that such qualified people can be only found in sufficient amount in the metropolitan areas of the South-East and South Region of Brazil. The FDI location factor "physical infrastructure" describes the importance of a developed road and a rail network for the investment decision. Two interviewed companies mentioned the importance of international airports, and the other two companies said that for them the close distance to a sea port is critical. The criteria "zero-FDI state investment criteria" describes what conditions have to be given in order to attract investment to Brazilian federal state as for instance in the north-east of the country, which according to the total sample have not received any German and Austrian FDI. It was found that labor qualification plays an important role. Two of the interviewed companies would invest in such zero-FDI investment states, if they would just need a low-qualified labor force. Another company stated that the proximity to a big sea port has to be given. A further interviewee emphasized that the local market needs to contain a sufficient amount of important companies for the investor. The investment criteria "export platform for Latin America" describes, whether using Brazil as export platform for other Latin American countries in general or for other MERCOSUR countries in particular influences the location decision of German and Austrian investment. It was found that this investment criterion is not important for the interviewed companies. The reason is that two interviewees exclusively sell their products in Brazil, whereas the other two, do not consider the factor to have an influence on geographical location of the business within Brazil. The FDI location factor "tax incentives" describes whether German and Austrian companies would prefer to locate in Brazilian federal states, which provide them any kind of tax or other financial incentive. Two interviewees stated that the tax incentives would be a factor to consider, but its importance depends on the size of the investment. One interviewed company, to which tax incentives were actually offered, stated that after the transport network, this would be the next factor to consider for their planned production facility.

\section{Conclusion}

Our empirical analysis showed that agglomeration seems to be an important FDI location choice factor for German and Austrian investors in Brazil. However, as the concept of agglomeration is a very complex one, it was important to find out, which forces had a significant influence. The analysis showed that the past investment decisions of German and Austrian companies had a significant influence on the location of the new ones. The quantitative analysis found that these companies tend to locate near the most important clients, which can be found near Sao Paulo and few other bigger metropolitan areas in the Southeast and South Regions of the country. However, taking into account all investment decisions, the overall industrial and urban development of a Brazilian federal state does not have a general significant influence on the investment location decision. A further factor is the aspect of workforce education. German and Austrian companies, investing in Brazil, are overall B2B companies, which work together with other Brazilian or MNEs and require a skilled labor force. These companies require especially Brazilian employees with good technical and English language skills, which mainly can be found in big cities and again especially in Sao Paulo. The statistical analysis found that the share of people with tertiary education has a significant influence on the FDI location decision in all observed federal states. The next finding concerns the industries of the foreign investing companies. Companies of different industries might have different FDI location choice preferences due to the nature of their industries. As most German and Austrian companies in Brazil are in the industrial transformation industries (Deutsche Bundesbank, 2013; Austrian Trade Commission, 2013), this fact could be easily overlooked. However, the statistical analysis showed that companies, which invested outside of Sao Paulo in the states of Rio de Janeiro and Rio Grande do Sul operate mostly in the IT and service industries. Therefore, these companies seem to find the same preferred industry-specific conditions also in these two specific federal states outside of Sao Paulo, as well. Although Sao Paulo has the biggest market of Brazil, economic activity as such was not found to be a significant factor for FDI location choice.

According to the findings of qualitative analysis German and Austrian companies in Brazil mainly locate close to their most important customers. These customers can be usually found in big Brazilian metropolis like Sao Paulo, Rio de Janeiro or Curitiba. These Brazilian cities provide two highly important advantages for German and Austrian 
companies; on the one hand, a pool of qualified people, who talk English and have a technical background or technical understanding, on the other hand, international physical infrastructure connections like an international airport or sea port. When focusing on cheap manufacturing only, the international physical infrastructure is required and the qualified labor pool is critical, as well. If these preconditions are met, German and Austrian companies would go after tax incentives. According to this conclusion, agglomeration in connection with qualified labor and international physical infrastructure connections would explain why German and Austrian B2B companies, which mainly sell high technology imported goods in Brazil, locate in the some parts of Brazil and not in the others. However, due to the limited sample size in the qualitative analysis, the presented findings have to be regarded as a supportive tool to better interpret some aspects of the quantitative research.

The first limitation of this paper concerns sample in the quantitative analysis, which contains observations from 2001 to 2011. Therefore, conclusions could be made only within this time-frame and thus by looking back in the past. All kinds of future predictions are of speculative nature and have to be seen in this way. Furthermore, in spite of representing a large portion of German and Austrian company-specific FDI in Brazil, the sample does not represent all observations. In addition, the variables used to represent the FDI location choice factors of interest are proxies and therefore cannot always fully represent what they were set out to measure. Another important aspect to keep in mind are unobserved regions of Brazil, which were not included in the analysis due to the non-existence of FDI. Hence, conclusions could be only drawn from Brazilian federal states, which were explicitly included in the statistical analysis. Finally, any generalizations for other countries investing in Brazil or for overall Brazilian regional inward FDI, as well as the FDI location choice factors in other emerging or developed countries on national or regional level cannot be made from exclusively considering this paper.

Future research on FDI location choice factors in Brazilian regions should focus on investor nations, where a bigger company-specific sample is available. Another way would be to include as many company-specific observations as possible, independent from the investor nation. Furthermore, different or additional variables as for instance transport costs or wage levels should be taken into account. Due to a lack of investment data for longer time frames and imperfect proxy variables for the statistical analysis, a qualitative empirical analysis should be implemented in future studies about FDI location choice factors in Brazil and in other emerging markets, as well.

\section{References}

Alcácer, J., \& Chung, W. (2007). Location strategy and knowledge spillovers. Management Science, 53(5), 760-776. http://dx.doi.org/10.1287/mnsc.1060.0637

Arthur, W. (1990). Positive Feedbacks in the Economy. Scientific American, 262(2), 92-99. http://dx.doi.org/10.1038/scientificamerican0290-92

AT Kearney. (2013). The A.T. Kearney Foreign Direct Investment Confidence Index: Back to Business: Optimism Amid Uncertainty. $\quad$ Retrieved $10 \quad$ January 2014, from http://www.atkearney.com/documents/10192/1464437/Back+to+Business+-+Optimism+Amid+Uncertainty+-+ FDICI+2013.pdf/96039e18 5d34-49ca-9cec-5c1f27dc099d

Audretsch, D.B., \& Feldman, M.P. (1996). R\&D spillovers and the geography of innovation and production. American Economic Review, 86(3), 630-640.

Austrian Trade Commission in Brazil. (2013). Österreichische Firmen mit Niederlassungen in Brasilien. Retrieved 30 June 2013, from http://www.advantageaustria.org

Basile, R. (2002). Acquisition versus greenfield investment: The location of foreign manufacturers in Italy. Regional Science and Urban Economics, 34(2), 3-25.

Békés, G. (2005). Location of Manufacturing FDI in Hungary: How important are inter-company relationships?, MNB Working Paper, No. 2005/7.

Belderbos, R., \& Carree, M. (2002). The Location of Japanese Investments in China: Agglomeration Effects, Keiretsu, and Firm Heterogeneity. Journal of the Japanese and International Economies, 16(2), 194-211. http://dx.doi.org/10.1006/jjie.2001.0491

Belderbos, R., Olffen, W. V., \& Zou, J. (2011). Generic and specific social learning mechanisms in foreign entry location choice. Strategic Management Journal, 32(12), 1309-1330. http://dx.doi.org/10.1002/smj.938

Binh, D.T.T. (2010). Agglomeration Economies and Location Choices by Foreign Investors in Vietnam. Kompetenzzentrum. Forschungsschwerpunkt Internationale Wirtschaft, FIW Working Paper Nr. 45, pp. 1-43. 
Blonigen, B. A., Ellis, C. J., \& Fausten, D. (2003). Industrial Groupings and Foreign Direct Investment. Journal of International Economics, 65(1), 75-91. http://dx.doi.org/10.1016/j.jinteco.2003.12.003

Boermans, M. A., Roelfsema, H., \& Zhang, Y. (2011). Regional determinants of FDI in China: a factor-based approach. Journal of Chinese Economic and Business Studies, 9(1), 23-42. http://dx.doi.org/10.1080/14765284.2011.542884

Bortoluzzo, M. M., Sakurai, S. N., \& Bortoluzzo, A. B. (2012). Alocação do Investimento Direto Externo entre estados brasileiros, Insper Working Papers, WPE: 269/2012, pp. 1-21.

Buccllato, T., \& Santangelo, F. (2009). Foreign Direct Investment Distribution in the Russian federation: Do spatial effects matter? Centre for the Study of Economic and Social Change in Europe, Economics Working Paper No. 99, pp. 1-30.

Büttner, T., \& Ruf, M. (2004). Tax Incentives and the Location of FDI: Evidence from a Panel of German Multinationals, Centre for European Economic Research, Discussion Paper No. 04-76, pp. 1-23.

Cantwell, J. A., \& Mudambi, R. (2011). Physical attraction and the geography of knowledge sourcing in multinational enterprises. Global Strategy Journal, 1(3-4), 206-232. http://dx.doi.org/10.1002/gsj.24

Chang, S. J., \& Park S. (2005). Types of firms generating network externalities and MNCs' co-location decisions. Strategic Management Journal, 26(7), 595-615. http://dx.doi.org/10.1002/smj.464

Chidlow, A., Salciuviene, L., \& Young, S. (2009). Regional determinants of inward FDI distribution in Poland. International Business Review, 18(2), 119-133. http://dx.doi.org/10.1016/j.ibusrev.2009.02.004

Chung, W., \& Alcácer, J. (2002). Knowledge Seeking and Location Choice of Foreign Direct Investment in the United States. Management Science, 48(12), 1534-1554. http://dx.doi.org/10.1287/mnsc.48.12.1534.440

Cobos, S., Görg, H., \& Strobl, E. (2002). Multinationals' location choice, agglomeration economies and public incentives, Leverhulme Centre for Research on Globalisation and Economic Policy, Research paper No. 2002/33, pp. 1-36.

Crozet, M., Mayer, T., \& Mucchielli, J.L. (2004). How do firms agglomerate? A study of FDI in France. Regional Science and Urban Economics, 34(1), 27-54. http://dx.doi.org/10.1016/S0166-0462(03)00010-3

DeAngelo, C., Eunni, R. V., \& Fouto, N. M. M. D. (2010). Determinants of FDI in emerging markets: evidence from Brazil. International Journal of Commerce and Management, 20(3), 203-216. http://dx.doi.org/10.1108/10569211011076901

Deichmann, J., Karidis, S., \& Sayek, S. (2003). Foreign direct investment in Turkey: regional determinants. Applied Economics, 35(16), 1767-1778. http://dx.doi.org/10.1080/0003684032000126780

Deutsche Bundesbank (2013) Bestandserhebung über Direktinvestitionen. Statistische Sonderveröffentlichung, Frankfurt am Main: Deutsche Bundesbank.

Dimitropoulou, D., Burke, S., \& McCann, P. (2013). The Determinants of the Location of Foreign Direct Investment in UK Regions. Applied Economics, 45(27), 3853-3862. http://dx.doi.org/10.1080/00036846.2011.558482

Disdier, A.C., \& Mayer T. (2004). How different is Eastern Europe? Structure and determinants of location choices by French firms in Eastern and Western Europe. Journal of comparative Economics, 32(2), 280-296. http://dx.doi.org/10.1016/j.jce.2004.02.004

Du, J., Lu, Y., \& Tao, Z. (2008). Economic institutions and FDI location choice: Evidence from US multinationals in China. Journal of Comparative Economics, 36(3), 412-429. http://dx.doi.org/10.1016/j.jce.2008.04.004

Ellison, G., \& Glaeser, E. L. (1997). Geographic Concentration in U.S. Manufacturing Industries: A Dartboard Approach. Journal of Political Economy, 105(5), 889-927. http://dx.doi.org/10.1086/262098

German-Brasilien Chamber of Commerce and Industry. (2013). Key Facts Brasilien-Deutschland. Retrieved 9 February 2013, from http://www.ahkbrasilien.com.br/fileadmin/ahk_brasilien/download_dateien/keyfacts_setembro_2012.pdf

Glaeser, E. L., Kallal, H. D., \& Scheinkman, J. A. (1992). Growth in Cities. Journal of Political Economy, 100(6), 1126-1152. http://dx.doi.org/10.1086/261856 
Glickman, N.J., \& Woodward, D.P. (1988). The Location of Foreign Direct Investment in the United States: Patterns and Determinants. International Regional Science Review, 11(2), 137-154. http://dx.doi.org/10.1177/016001768801100203

Guimaraes, P., Figueiredo, O., \& Woodward, D. (2000). Agglomeration and the Location of Foreign Direct Investment in Portugal. Journal of Urban Economics, 47, 115-135. http://dx.doi.org/10.1006/juec.1999.2138

Head, K., Ries, J., \& Swenson, D. (1995). Agglomeration benefits and location choice: Evidence from Japanese manufacturing investment in the United States. Journal of International Economics, 38, 223-247. http://dx.doi.org/10.1016/0022-1996(94)01351-R

Henderson, J.V. (1997). Externalities and Industrial Development. Journal of Urban Economics, 42, 449-470. http://dx.doi.org/10.1006/juec.1997.2036

Henderson, V., Kuncoro, A., \& Turner, M. (1995). Industrial Development in Cities. Journal of Political Economy, 103(5), 1067-1090. http://dx.doi.org/10.1086/262013

Hilber, C. A. L., \& Voicu, I. (2007). Agglomeration Economies and the Location of Foreign Direct Investment: Empirical Evidence from Romania, Mimeo, London School of Economics, London, UK.

Huallachain, B., \& Reid, N. (1997). Acquisition versus Greenfield Investment: The location and growth of Japanese manufacturers in the United States. Regional Studies, 31(4), 403-416. http://dx.doi.org/10.1080/00343409750133008

Kandogan, Y. (2012). Regional foreign direct investment potential of the states within the US. Journal of Economics and Business, 64(4), 306-322. http://dx.doi.org/10.1016/j.jeconbus.2012.03.004

Kang, H. H., \& Huang, S. R. (2012). An analysis of the determinants of inward direct investment in Brazil in Proceedings of ASBBS Las Vegas, Vol. 19, pp. 472-487.

Kinoshita, Y., \& Campos, N. F. (2003). Why does FDI Go Where it Goes? New Evidence from the Transition Economies, IMF Working paper, WP/03/228, pp. 1-31.

Kornecki, L., \& Ekanayake, E. M. (2012). State Based Determinants of Inward FDI Flow in the US Economy. Modern Economy, 3(3), 302-309. http://dx.doi.org/10.4236/me.2012.33040

Kostova, T., \& Zaheer, S. (1999). Organizational legitimacy under conditions of complexity: The case of the multinational enterprise. Academy of Management Review, 24(1), 64-81. http://dx.doi.org/10.5465/AMR.1999.1580441, http://dx.doi.org/10.2307/259037

Kozlowski, P. J., \& Weekly, J. K. (1990). Interstate Investment USA. Regional Science Perspectives, 20(2), 3-25.

Lamin, A., \& Livanis, G. (2013). Agglomeration, catch-up and liability of foreignness. Journal of International business Studies, 44, 579-606. http://dx.doi.org/10.1057/jibs.2013.14

Law, S.H. (2010). Location Decision for Foreign Direct Investment in ASEAN Countries: A TOPSIS Approach. International Research Journal of Finance and Economics, 36, 197-207.

Ledyaeva, S., Karhunen, P., \& Kosonen, R. (2010). Determinants of location choice of Chinese, Japanese and US direct investment in Russia, Aalto University School of Economics, Helsinki.

Lee, K.D., Hwang, S.J., \& Lee, M.H. (2012). Agglomeration economies and location choice of Korean manufacturers within the United States. Applied Economics, 44(2), 189-200. http://dx.doi.org/10.1080/00036846.2010.502109

Maniam, B. (2007). An empirical investigation of U.S. FDI in Latin America. Journal of International Business Research, 6(2), 1-15.

Martin, R. (1999). The new' geographical turn' in economics: Some critical reflections. Cambridge Journal of Economics, 23(1), 65-91. http://dx.doi.org/10.1093/cje/23.1.65

Mayring, P. (2001). Kombination und Integration qualitativer und quantitativer Analyse. Forum Qualitative Sozialforschung/ Forum: Qualitative Social Research 2(1), Art. 6 Retrieved 20 July, 2013, from http://www.qualitative-research.net/fqs-texte/1-01/1-01 mayring-d.htm

McFadden, D. (1973). Conditional Logit Analysis of Qualitative Choice Behavior. In P. Zarembka (Ed.), Frontiers of Econometrics (pp.105-142). Academic Press, New York.

Meyer, K. E., Mudambi, R., \& Narula, R. (2011). Multinational enterprises and local contexts: The opportunities and challenges of multiple embededness. Journal of Management Studies, 48(2), 235-252. 
Meyer, K. E., Wright, M., \& Pruthi, S. (2009). Managing knowledge in foreign entry strategies: A resource-based analysis. Strategic Management Journal, 30(5), 557-574. http://dx.doi.org/10.1002/smj.756

Mukim, M., \& Nunnenkamp, P. (2012). The Location Choices of Foreign Investors: A District-level Analysis in India. The World Economy, 35(7), 886-918. http://dx.doi.org/10.1111/j.1467-9701.2011.01393.x

Na, L., \& Lightfoot, W. S. (2006). Determinants of foreign direct investment at the regional level in China. Journal of Technology Management in China, 1(3), 262-278. http://dx.doi.org/10.1108/17468770610704930

Neary, J. P. (2000). Of hype and hyperbolas: Introducing the new economic geography. Journal of Economic Literature, 49(4), 536-561.

Nelson, R. (2002). State Competition for Foreign Direct Investment in Brazil: The Case of Dell Computer. The Brown Journal of World Affairs, 8(2), 139.153.

Schmidheiny, K., \& Brülhart, M. (2009). On the equivalence of location choice models: Conditional logit, nested logit and Poisson. Journal of Urban Economics, 69, 214-222. http://dx.doi.org/10.1016/j.jue.2010.09.004

Sethi, D., Judge. W., \& Sun, Q. (2011). FDI distribution within China: An integrative conceptual framework for analysing intra-country FDI variations. Asia Pacific Journal of Management, 28(2), 325-352. http://dx.doi.org/10.1007/s10490-009-9144-5

Shaver, J. M., \& Flyer, F. (2000). Agglomeration Economies, Firm Heterogeneity, and Foreign Direct Investment in the United States. Strategic Management Journal, 21(12), 1175-1193. http://dx.doi.org/10.1002/1097-0266(200012)21:12<1175::AID-SMJ139>3.3.CO;2-H

Sridhar, K. S., \& Wan, G. (2007). Firm location choice in cities: Evidence from China, India and Brazil, UNU-WIDER, Research Paper No. 2007/56, pp. 1-21.

Tan, D., \& Meyer, K. E. (2011). Country-of-origin and industry FDI agglomeration of foreign investors in an emerging economy. Journal of International Business Studies, 42(4), 504-520. http://dx.doi.org/10.1057/jibs.2011.4

Ulgado, F., \& Yu, C. J. (1991). The Location of Manufacturing Foreign Direct Labor Investment in the United States: The Effects of Nationality and Firm-Specific Variables, Georgia Institute of Technology, Working Paper Series 97-017, pp. 1-36.

Ulgado, F. M., \& Lee, M. (2004). The effects of nationality differences on manufacturing location in the US: a conjoint analysis approach. International Business Review, 13(4), 503-522. http://dx.doi.org/10.1016/j.ibusrev.2004.04.001

UNCTAD. (1992). World Investment Report. Transnational Corporations as Engines of Growth, United Nations, New York.

UNCTAD. (2012). World Investment report 2012: Towards a new generation of investment policy, United Nations, Geneva.

Zaheer, S., \& Mosakowski, E. (1997). The dynamics of the liability of foreignness: A global study of survival in financial services. Strategic Management Journal, $18(6), \quad 439-464$. http://dx.doi.org/10.1002/(SICI)1097-0266(199706)18:6<439::AID-SMJ884>3.3.CO;2-P

Zhou, C., Delios, A., \& Yang, J. Y. (2002). Locational Determinants of Japanese Foreign Direct Investment in China. Asia Pacific Journal of Management, 19, 63-86. http://dx.doi.org/10.1023/A:1014839607180 